Fikrah: Jurnal Ilmu Aqidah dan Studi Keagamaan

issn 2354-6174 eissn 2476-9649

Tersedia online di: journal.iainkudus.ac.id/index.php/fikrah

Volume 8 Nomor 12020 , (1-24)

DOI: 10.21043/fikrah.v8i1.6525

\title{
Dimensi Estetika dan Identitas Budaya dalam Bangunan Keraton Surakarta
}

\author{
Siti Nurlaili Muhadiyatiningsih \\ IAIN Surakarta, Sukoharjo, Indonesia \\ ahlaili67.nl@gmail.comSF \\ Siti Fathonah \\ IAIN Surakarta, Sukoharjo, Indonesia \\ st.fathonaho1@gmail.com
}

\begin{abstract}
Abstrak
Keraton Kasunanan Surakarta adalah salah satu situs bersejarah penting dalam persebaran Islam di wilayah Jawa. Akulturasi antara beberapa aspek yang terwujud dalam bangunan keraton adalah simbol-simbol sarat makna yang menarik untuk dibahas. Artikel ini ingin mendiskusikan tentang dimensi estetika dan identitas budaya yang tersimpan dalam bangunan Keraton Kasunanan Surakarta. Data dalam tulisan ini diambil melalui metode kualitatif dengan pendekatan pustaka, observasi dan wawancara mendalam. Melalui teori simbol dan identitas, temuan dalam tulisan ini menyajikan dua hal. Pertama, estetika dan identitas budaya yang banyak dihubungkan dengan terminologi Jawa nyatanya banyak dihubungkan dengan konsep kultural dalam etika Jawa, yaitu pantas-tidak pantas, dan indah-tidak indah. Kedua, dalam konteks identitas, ditemukan beberapa pesan yang merepresentasikan ajaran Islam dan produk budaya Jawa-Eropa. Adapun secara keseluruhan, susunan bangunan dalam Keraton Kasunanan Surakarta menyimpan makna simbolis penyucian diri manusia menjadi insan kamil melalui beberapa jalan dalam ajaran thariqah dalam tasawuf.
\end{abstract}

Kata kunci: estetika, identitas budaya, keraton kasunanan surakarta, simbol. 


\begin{abstract}
Karaton Kasunanan Surakarta is one of the important historic sites in the spread procces of Islam in java. Acculturation between several aspects that manifested in building are symbols full of meaning that is interesting to discuss. This article wants to discuss about the aesthetic dimensions and cultural identity stored in the Surakarta Kasunanan palace building. Through symbol theory and identity, the interim findings in this paper are firstly the aesthetics and cultural identity which are much associated with beauty in Javanese terminology cannot be separated from being appropriate, inappropriate, and beautiful, not beautiful. Secondly, in the context of identity, there are stored messages that represent Islamic teachings and Javanese-European culture. As for the whole, the structure of the building in the palace of the Surakarta Sunanate keeps the symbolic meaning of human purification into a human being through several ways in the teachings of Tariqah.
\end{abstract}

keywords: aestetic, cultural identity, keraton kasunanan surakarta, symbol.

\title{
Pendahuluan
}

Negara saya gendra, jalaran Cina menang lan ngangkat Sunan Anyar kang jejuluk SUNAN KUNING. Sri Susuhunan Paku Buwana II lolos seka karaton jalaran dikepung mungsuh, ngungsi menyang tlatah Panaraga nganti kira-kita setengah tahun lan didampingi dening Pangeran Adipati Anom lan Van Hohendorff. Nanging kapten Walanda mau ora suwe tumuli menyang Suroboyo, lan saka kana banjur lelayar metu segara menyang Betawi, lapur pemimpine.

(Dikutip dari (Sajid, 1984))

Kutipan di atas adalah narasi dalam Babad Sala yang menceritakan perihal awal mula runtuhnya kekuasaan kerajaan Mataran Kartasura di bawah abad kepemimpinan Sunan Pakubuwono II (Nurhajarini, 1999: 71). Keruntuhan kerajaan Mataram Kartasura bermula dari konflik keluarga berbasis kekuasaan yang selanjutnya dimanfaatkan kompeni untuk melancarkan politik adu domba. Beberapa saat setelah kerusuhan dan Kartasura kembali bisa direbut oleh Sunan Pakubuwono II dengan bantuan kompeni Belanda, terjadi beberapa peristiwa politik penting. Bonus yang diterima oleh Belanda melalui perjanjian Giyanti saat itu adalah berupa wilayah kekuasaan di kawasan Jawa. Akta perjanjian yang dikenal dengan acte van afstand en overgave tersebut selalu diperbarui setiap terjadi pergantian penguasa. Hal paling signifikan dalam perjanjian tersebut adalah aturan soal pepaatih dalem. Patih menerima gaji dari pihak Belanda dan Keraton, namun apabila terjadi pergesekan antara Keraton dengan Belanda, Patih harus memihak Belanda. Meskipun Kartasura kembali bisa direbut, secara fungsional, keraton Kartasura tidak dapat difungsikan kembali karena mengalami kerusakan yang sangat mengkhawatirkan. Oleh sebab itu Sunan 
Pakubuwono II memutuskan untuk mendirikan keraton di tempat yang baru, yaitu Desa Sala.

Keraton Surakarta adalah salah satu situs bersejarah di pulau Jawa yang juga dikenal sebagai Keraton Kasunanan Surakarta Hadiningrat. Keraton yang terletak di tengah pulau Jawa ini merupakan salah satu simbol atas terjadinya peristiwa pemberontakan yang dipimpin oleh Raden Mas Gerandi atau yang dikenal sebagai Sunan Kuning (Winarti, 2002). Lahirnya Keraton Surakarta berawal dari ketidakmungkinan ditempatinya kembali Keraton Kartasura pasca berhasil direbut kembali oleh Susuhunan Pakubuwono II karena kondisi keraton yang telah rusak. Susuhunan Pakubuwono II yang selanjutnya diketahui bersekutu dengan Mayor Van Hohendorff memutuskan untuk mencari tempat baru untuk mendirikan keraton pengganti Kartasura, maka lahirlah Keraton Kasunanan Surakarta ( Nurhajarini, 1999). Latar belakang sejarah mengenai dipindahkannya keraton yang baru inilah yang membawa peneliti mengasumsikan bahwa banyak makna simbolik yang ada pada bangunan Keraton Surakarta, yaitu keraton yang baru. Dalam tulisan ini peneliti ingin mendeskripsikan makna yang tersimpan di balik wujud fisik bangunan-bangunan yang manjadi bagian dari Keraton Kasunanan Surakarta.

Desain Keraton Surakarta sebagai tempat tinggal penguasa Jawa yang dianggap sebagai senopati perang, pemimpin pemerintahan dan pemuka agama ini secara tidak langsung membuat bangunan keraton menjadi sakral. Pemilihan lokasi keraton dilakukan melalui beberapa ritual khusus oleh 4 utusan Sunan Pakubuwono, mulai dari membuat pancangan hingga tapa mati raga (Nurhajarini, 1999: 74). Dalam kepercayaan masyarakat Jawa, Keraton Surakarta adalah 'Pusering Tanah Jawi' yang berarti titik pusat dan sumber kebudayaan Jawa (Santosa, 2007), sehingga makna tidak hanya ditelusuri dari bentuk bangunannya saja tetapi juga pada susunan penamaan bangunanbangunannya. Penamaan bangunan keraton dipengaruhi oleh letak dan fungsi bangunan melalui sebuah laku yang dikenal dengan prosesi 'nitik karaton', yaitu usaha mencari dan memilih tempat yang dianggap baik. Ada sebentuk dimensi makrokosmos yang harus disatukan dengan mikrokosmos sehingga menghasilkan estetika bangunan yang karismatik. Bahkan, pertimbangan magis kejawen dan laku batin juga dijiwai oleh arsitek atau pencetus bentuk bangunan. Prosesi tersebut juga tampak sesuai dengan tesis Rapoport, ia mengkaji mengenai arsitektur tradisional, dalam pembahasanya sebagian besar bangunan adalah gambaran duniawi yang bercitra surgawi, mempersatukan poros dunia antara jagad gedhe dengan jagad cilik (Rapoport, 1982: 69). 
Penelitian tentang makna simbolis dari bangunan keraton sebenarnya sudah banyak dilakukan oleh peneliti terdahulu. Hasil dari penelusuran pustaka yang peneliti lakukan ditemukan bahwa rata-rata penelitian terdahulu mengambil objek penelitian salah satu bagian keraton, baik dalam bentuk bangunan, tradisi maupun kajian tokoh. Misalnya; konsep mitologi dan makna simbolis yang tersimpan dalam Sasana Sewaka (Haryono, 2010), kajian semiotik terhadap struktur pemukiman Baluwarti (Haryati, 2014), nilai dalam tari Bedhaya, tari Srimpi di Keraton Surakarta (Tsabita, 2018, Bari, 2018), dan kiprah G.R.Ay. Koes Moertijah dalam salah satu tradisi dan organisasi di Keraton (Haryanti, 2001). Namun demikian, peneliti menemukan beberapa penelitian yang memiliki kedekatan relasi dengan artikel ini. Kajian dengan tinjauan semanti arsitektur Jawa pernah dilakukan terhadap Sasana Sewaka sebagai salah satu bagian dari keseluruhan unsur bangunan di keraton Surakarta (Nilasari, 2013). Penelitian tersebut menghasilkan temuan yang menyebutkan bahwa terdapat perjumpaan arsitektur Eropa dalam bangunan Keraton Surakarta, dan penamaan wujud arsitektur yang berupa bangunan menyimpan makna yang ingin dikomunikasikan.

Penelusuran tentang morfologi dalam penamaan berbagai bangunan keraton Surakarta juga pernah dilakukan dimana dalam penelusuran tersebut temuan bahwa nama-nama bangunan keraton Surakarta terdiri dari minimal satu suku kata dan maksimal tiga suku kata. Penamaan tersebut adalah simbol dari berbagai peristiwa, keadaan, dan fungsi yang melekat pada bangunanbangunan tertentu. Lebih jauh, makna-makna itu menyasar pesan-pesan moral yang banyak digunakan sebagai tuntunan hidup masyarakat Jawa. Bentuk dan makna bangunan pokok di karaton Surakarta juga pernah diteliti oleh dengan hasil temuan yang memperlihatkan bahwa bentuk bangunan berpengaruh pada penamaan bangunan, dan makna dari masing-masing bangunan terdiri dari makna leksikal, kultural dan filosofi. Secara khusus, frame estetika juga pernah dipakai untuk membatasi penelitiannya tentang arsitektur bangunan masjid agung Surakarta (Yunianti, 2015). Secara visual, arsitektur masjid Surakarta memiliki beberapa persamaan dengan Joglo sebagai rumah tradisional Jawa. Selain menyimpan pesan estetis, arsitektur masjid juga memiliki makna yang berasal dari kearifan lokal.

Salah satu pandangan yang diproduksi oleh budaya dalam asumsi penelitian tentang keraton ini adalah saratnya nilai dan makna yang tersimpan pada bentuk bangunan. Pesan simbolis ini selanjutnya dimaknai 
oleh manusia lain dalam kedudukannya sebagai penerima pesan. Makna yang diproduksi oleh pengirim pesan bisa sesuai dengan yang diterima oleh penerima pesan, atau sebaliknya. Di sinilah kemudian unsur yang mengiringi terbentuknya makna pesan menjadi sangat penting. (Koentjaraningrat, 2010).

\section{Metode}

Tulisan ini menggunakan metode analisis deskripsi dalam menginterpretasi dimensi estetika dan identitas yang tampak dalam bangunan Keraton Kasunanan Surakarta. Proses awal pengumpulan data dilakukan dengan cara mencari berbagai tulisan, baik berupa artikel jurnal maupun teks literature buku yang membahas mengenai berbagai tema yang berkaitan dengan keraton Surakarta. Wawancara mendalam secara intensif dilakukan dengan KGPH Poeger dan timnya sebagai informan kunci berdasarkan asumsi bahwa subjek yang tinggal di Keraton dan atau yang pernah tinggal di keraton lebih mengetahui filosofi bangunan keraton dibandingkan masyarakat biasa. Wawancara dilakukan untuk mendengarkan langsung mengenai berbagai makna filosofis dari setiap unsur bangunan di Keraton Surakarta. Selain itu ada beberapa informan biasa yang berasal dari masyarakat luar yang tinggal di sekitar Keraton dan beberapa informan tambahan.

Selain wawancara dan observasi, dokumentasi juga dilakukan untuk melihat perubahan bentuk atau fungsi bangunan Keraton Surakarta saat ini. Obeservasi dimulai dari titik terluar Keraton, yaitu Tugu Pamandengan yang terletak di halaman Balai Kota Surakarta hingga bagian paling selatan, yaitu Gapurendra. Dokumentasi dilakukan atas unsur bangunan paling luar dari arah utara (Tugu Pamandengan) hingga paling luar dari arah selatan (Gapurendra).

\section{Representasi Keraton Kasunanan Surakarta dan Unsur-Unsur Bangunannya}

Secara umum, pembagian keraton meliputi; Tugu Pamandengan dan Kompleks Alun-alun Lor, Kompleks Sasana Sumewa, Kompleks Sitihinggil Lor, Kompleks Kamandungan Lor, Kompleks Sri Manganti, Kompleks Kedhaton, Kompleks Magangan, Kompleks Sri Manganti Kidul Dan Kamadungan Kidul serta Kompleks Sitihinggil Kidul dan Alun-Alun Kidul. Penataan bangunan Keraton yang berawal dari Alun-alun Utara menuju Kedhaton mengandung makna filosofi tentang perjalanan hidup manusia 
yang akan berakhir dengan perjumpaanya dengan Tuhan (KGPH Poeger, 2019). Selanjutnya, filosofi penataan bangunan dari Kedhaton menuju Alunalun Selatan adalah kembalinya manusia ke alam baka atau kelanggengan, makna dalam penataan unsur keraton juga menyasar bagaimana posisi manusia sebagai subjek yang memegang kontrol terhadap pengendalian hawa nafsu. Semakin manusia menjadi tua dan memahami fenomena hidup serta memiliki pengalaman hidup yang bermacam-macam maka manusia semakin bisa mengontrol perilaku menjadi seimbang dalam memaknai keberadaan dunia dan akhirat. Menurut informan dalam salah satu momen interview yang telah peneliti lakukan juga diketahui bahwa alun-alun utara hingga Kedhaton memiliki nilai filosofis perjalanan hidup manusia yang akan kembali kepada Tuhan atau yang dikenal dengan istilah Jawa 'sangkan paraning dumadi'.

Selanjutnya, dari arah Kedhaton hingga Alun-alun Selatan mengandung makna proses kehidupan manusia menuju kehidupan yang kekal di alam baka atau kelanggengan (alam sunyosuri). Tumbuh-tumbuhan yang ditanam di Sitihinggil Utara juga memiliki makna khusus. Tumbuh-tumbuhan tersebut ditanam setelah raja mendapatkan petunjuk dari Allah Swt. Tujuan penanaman tumbuhan itu adalah untuk menciptakan harmonisasi antara manusia pada dimensi materiil dengan makhluk non materiil sehingga tidak ada pengaruh buruk yang masuk ke keraton.

\section{Artikulasi Makna Simbol dalam Kerangka Estetik dan Identitas Budaya}

Simbol memproduksi pola hubungan rangkap tiga; pertama, 'tampilan simbol'; kedua, 'hubungan acuan'; dan ketiga, 'makna yang diwakili'. 'Tampilan simbol' bisa berupa sebuah kata atau barang atau obyek atau ungkapan bahasa atau tindakan, atau peristiwa, atau pola lambang, dan halhal konkret lainnya. Dalam hal ini 'tampilan simbol' adalah bentuk bangunan-bangunan dan penataannya, serta berbagai bentuk materiil empirik yang menempel pada bangunan/ benda di Keraton. Misalnya, bentuk Tugu Pamandengan, Gapura Gladak, atap masjid, arsitektur Sitihinggil dan beberapa bangunan lainnya di Keraton. Berikutnya adalah pola 'hubungan acuan' bisa berupa yang mewakili atau menggambarkan atau menyandikan atau mengisyaratkan atau menggugah atau mengingatkan atau merujuk kepada atau menggantikan atau berserasian dengan atau yang berarti. Misalnya, bangunan Sitihinggil Utara dengan Sitihinggil Selatan yang memiliki bentuk dan fungsi yang sangat berbeda. Pola yang terakhir adalah 'makna yang diwakili', biasanya berupa sesuatu yang lebih besar, atau sesuatu yang 
diidealkan masyarakat, atau suatu pandangan hidup, atau sesuatu yang transenden, atau yang tertinggi di alam sana sebagai suatu realitas, atau ideologi, atau kepercayaan. Misalnya, perbedaan bentuk bangunan antara Sitihinggil Utara dengan Sitihinggil Selatan merepresentasikan makna yang berbeda, lebih dalam dari bentuk kedua bangunan tersebut. Kemewahan yang bisa kita saksikan di Sitihinggil Utara tidak bisa kita lihat pada Sitihinggil Selatan. Pertanyaan yang muncul selanjutnya adalah mengapa perbedaan tersebut dibuat, lalu apa makna yang ingin disampaikan, dan siapa yang mewakili makna tersebut.

Kerangka berpikir simbolis membentuk mencerminkan isi. Jika dikontekstualisasikan dengan teori tersebut maka tentu berlaku asumsi bahwa bentuk bangunan keraton menyimpan makna, siapa yang memproduksi makna dan apa makna yang ingin disampaikan (Marlina, 2003). Dari sinilah penulis melihat bahwa ada keterkaitan antara bangunan Keraton dengan identitas pemilik bangunan yang terhubung dengan budaya yang berlangsung saat itu. Konsep simbol yang mengiringi terwujudnya sebuah bentuk pada dasarnya juga terdapat dalam konsep wadah dan isi dalam terminologi Jawa. Menurut Woodward (1999) terdapat dua macam bentuk dalam kehidupan, yaitu bentuk materiil dan non materiil. Bangunan adalah salah satu bentuk materiil yang strukturnya dapat diamati secara empiris.

Bangunan keraton merupakan cara penyandian yang sesuai untuk memperluas pandangan manusia, merangsang daya imajinasi dan memperdalam pemahaman manusia tentang dirinya, masyarakatnya, dan alam lingkungannya, baik fisik maupun metafisik. Dalam kajian tentang manusia dan kebudayaan, Cessirer (1987) menyebut manusia sebagai animal politicum dan animal symbolicum. Menurutnya, pemikiran simbolis dan tingkah laku simbolis merupakan ciri yang betul-betul khas manusiawi dan bahwa seluruh kebudayaan manusia mendasarkan diri pada kondisi-kondisi yang sedang berlangsung. Konsep ini juga berlaku ketika arsitek bangunan keraton menciptakan bentuk-bentuk bangunan seperti yang kita saksikan saat ini. Keraton Surakarta termasuk dalam situs kebudayaan Jawa yang kerap disandingkan dengan citra tentang keindahan dan pembahasan yang estetis (Suseno, 1984). Apa makna di balik keindahan-keindahan yang ditampilkan serta mengapa hal tersebut dilakukan.

Konsep keindahan hingga saat ini memang masih bersifat relative. Bagaimana sesungguhnya bentuk keindahan? Sejak Augustinus (354-430) hingga Aquinas (1225-1274) tidak ditemukan kesepakatan makna 
estetika/keindahan, kecuali bahwa kebenaran dan keindahan adalah dua hal yang sama. Dengan demikian, sejak awal estetika diasosiasikan sebagai keindahan yang benar, dan kebenaran dalam benak para filsuf adalah kebenaran yang mengandung nilai-nilai ke-Ilahian. Augustinus sebagaimana dikutip Santosa menyatakan bahwa keindahan adalah kesatuan bentuk (omnis pulcritudinis forma unitas est). Sedangkan Aquinas yang juga dikutip dari Manalu et al.,(2007) merinci keindahan sebagai segala bentuk yang memiliki; pertama, integritas/perfeksi; kedua, proporsi yang tepat/harmoni; ketiga, jelas. Teori keindahan Aquinas inilah yang akan digunakan untuk membingkai analisis dimensi estetika.

Chris van Rompaey (2017) yang mengutip Alexander Gottlieb Baumgarten (1714-1762) membedakan tiga kesempurnaan dalam disertasi doktoralnya. Pertama, kebenaran (das wahre) yaitu kesempurnaan yang bisa ditangkap melalui perantaraan rasio. Kedua, kebaikan (das gute) yaitu kesempurnaan yang bisa ditangkap melalui moral atau hati nurani. Ketiga, keindahan (das schone) yaitu kesempurnaan yang dapat ditangkap dengan indera. Ini berarti bahwa proporsi keindahan mulai ditawar, atau berbeda dengan pandangan lama. Keindahan tidak lagi harus memuat nilai kebenaran, melainkan sesuatu yang inderawi. Berawal dari sinilah muncul konsep persepsi sehingga estetika dimaknai sebagai the science of perceptual cognition. Dalam konteks kepercayaan masyarakat Jawa, nilai tertinggi atau konsep kesempurnaan tercermin melalui keselarasan (Suseno, 1984). Artinya sebuah wujud, baik berupa perilaku maupun ide yang mengarah pada pemeliharaan keselarasan atau harmoni itulah yang dinamakan kesempurnaan. Sebaliknya, segala sesuatu yang mengarah pada ketidak-selarasan atau kehancuran adalah kesalahan. Dalam relasi ini ada dua kata kunci yang dipakai untuk menegaskan unsur-unsur yang berkaitan dengan kesempurnaan tersebut, yaitu alus (halus), dan kasar. Istilah halus banyak dikenal untuk menyebut kehalusan permukaan, kehalusan kelakuan, kepekaan, ketampanan, kesopanan dan sebagainya. Sebaliknya, istilah kasar dikenal untuk menunjuk segala sesuatu yang berlawanan dengan kehalusan. Halus-kasar merupakan tolak ukur masyarakat Jawa untuk menilai sebuah gejala. Oleh sebab itulah halus-kasar dijadikan kategori estetis. Segala yang halus adalah indah dan yang kasar adalah jelek. Dengan demikian penilaian tentang baik-buruk dekat dengan penilaian estetis.

Hubungan antara estetika dan identitas terletak pada representasi budaya dan filosofi yang mendasarinya. Wujud yang indah dalam sebuah 
karya tentu membawa agenda besar yang ingin disampaikan oleh si subjek kebudayaan, yang tidak lain adalah manusia, sang creator kebudayaan. Identitas adalah konstruksi sosial yang kompleks karena ada proses pemaknaan dan tidak ahistoris. Proses pembangunan identitas ini berlangsung secara cair dan dinamis. Secara umum, identitas dibedakan menjadi 2 macam, yaitu identitas individu dan identitas sosial. Identitas individu mengarah pada cara pandang personal atau kelompok terhadap diri mereka (internal) sedangkan identitas sosial adalah cara pandang masyarakat terhadap kita, baik secara personal (dalam posisi kita sebagai individu) atau komunitas (kita sebagai bagian dari kelompok). Dikutip langsung dari Jenkis mengenai Identitas, ia memaparkan bahwa Identitas adalah

'....our understanding or who we are and of who other people, and reciprocally, other's people understanding of themselves and of others (which includes us)'.(Jenkins, 2004)

Dengan demikian, bagi Jenkins identitas sosial adalah sebuah proses bagi individu untuk membedakan dirinya dalam suatu relasi sosial. Oleh sebab itu, pada bagian ini terdapat proses yang kontradiktif antara satu orang dengan orang lainnya. Identitas adalah 'individual labelling' dan merupakan distingsi antara kita dengan mereka, antara diri dengan yang lain. Untuk bisa menampilkan identitas, diperlukan bentuk-bentuk representasi, yang menurut Barker (2009), antara lain tanda-tanda selera, kepercayaan, sikap dan gaya hidup. Bagi Jenkins, identitas seseorang akan benar-benar terbentuk saat individu paham dengan keberadaan 'dirinya' dan 'orang lain'. Setelah memahami identitas dirinya seseorang baru akan bisa memahami identitas budaya. Smith dalam Jenkins, (2004) mengidentifikasi identitas budaya sebagai 'a collective culture phenomenon' yang terdiri dari beberapa unsur, misalnya bahasa khusus, peristiwa-peristiwa penanda yang khusus, atau interpretasi kelompok terhadap simbol-simbol tertentu yang telah disepakati. Oleh sebab itu, identitas sangat berhubungan dengan konstruksi sosial yang terus berreproduksi tanpa henti.

Identitas budaya dapat dilihat dari dua sudut pandang, yaitu; pertama, identitas budaya sebagai 'wujud'; dan kedua, identitas budaya sebagai 'proses menjadi'. Sebagai sebuah 'wujud', identitas budaya dapat dilihat dari kesamaan sejarah yang membuat suatu kelompok menjadi satu meskipun terlihat tidak sama. Identitas budaya dapat didefinisikan melalui empat representasi yang mencakup ras, etnis barat, etnisitas tradisional dan gaya hidup (Friedman, 1995). Dengan demikian, benar adanya jika identitas 
budayalah yang mengantarkan manusia pada komunikasi global, sehingga mudah dikenal oleh ras lain yang berada di luar lingkuangan yang mereka tinggali (Roikan, 2013). Keragaman ras ini tidak bisa dipungkiri memberikan warna tersendiri dalam kebudayaan manusia. Ras, etnis, tradisi dan gaya hidup yang berbeda ini selanjutnya menjadi standarisasi untuk menyebut suatu kebudayaan. Misalnya, bentuk fisik pada ras Kaukasoid dianggap sempurna oleh ras Melayu. Hal itu mengacu pada tinggi badan, warna rambut dan kulit yang pirang dan putih, warna bola mata, bentuk hidung yang bagi orang Melayu, 'sangat indah' dan representasi dari bentuk ideal manusia. Sebaliknya, ras Kaukasoid melihat ras Melayu lebih eksotis sebab memiliki bentuk wajah dan tubuh khas (tinggi badan sedang, bola mata berwarna cokelat kehitaman dan kulit sawo matang). Identitas budaya tersebut memproduksi sudut pandang kesempurnaan dan idealitas, antara tampan, cantik atau eksotis. Selain itu identitas budaya juga akhirnya mereproduksi pandangan tentang tradisional dan modern. Sudah menjadi kesepakatan umum bahwa standarisasi kesempurnaan direpresentasikan oleh ras Kaukasoid, baik dari sudut pandang intelektualitas, gaya hidup maupun bentuk fisik. Sedangkan selain suku Kaukasoid dianggap sebagai 'yang tradisional, atau terbelakang' (Hobart, 2013). Kondisi inilah yang mengantarkan penelitian ini untuk menganalisis identitas yang tersimpan dalam unsur bangunan Keraton Kasunanan Surakarta. Identifikasi identitas ini selanjutnya akan memberikan gambaran mengenai subjek yang membentuk kebudayaan dalam wujud simbol bangunanan Keraton Kasunanan Surakarta dan unsur-unsur pelengkapnya.

Ekspresi dalam arsitektur bangunan keraton apabila ditilik dari sudut pandang identitas mencerminkan identitas pribadi serta kelompok, baik dalam konteks kebiasaan maupun status sosial. Kebiasaan dan status tersebut bisa jadi mencerminkan kepercayaan yang dianut. Keraton Surakarta merupakan salah satu istana terbesar di Indonesia yang pembangunannya mengadopsi gaya bangunan Eropa. Kondisi tersebut disebabkan oleh adanya masa kolonialisme dunia di sekitar abad ke 17. Oleh karena itu tidaklah mengherankan jika pola dasar tata ruang Keraton Surakarta banyak memiliki persamaan secara umum dengan kerajaan di negara Eropa. Pola arsitektur di beberapa bagian bangunan mengalami penyesuaian bentuk antara Jawa dengan Eropa ( Marlina, 2003). Sebagian besar Keraton ini bernuansa warna putih dan biru dengan arsitektur gaya campuran Jawa-Eropa. 


\section{Dimensi Estetika dalam Bangunan Keraton Kasunanan Surakarta}

Seluruh bangunan yang terdapat pada Keraton Kasunanan Surakarta pada dasarnya memiliki makna. Dalam konteks sistem sosial, tempat-tempat atau ruang dalam Keraton memiliki ketentuan khusus terhadap siapa saja yang boleh mengakses dan masuk ke dalamnya. Disinilah desain bangunan memproduksi bentuk-bentuk estetik tertentu untuk merepresentasikan nilai dan makna. Keseluruhan bangunan Keraton, sebagaimana disampaikan oleh beberapa penelitian terdahulu adalah simbol perjalanan hidup dengan landasan nilai-nilai religius yang mengandung nilai ke-Ilahian. Inilah dimensi estetika bangunan Keraton Kasunanan Surakarta. Sebagaimana disinggung pada pembahasan sebelumnya bahwa dalam pembangunannya dahulu, Keraton Surakarta mempersyaratkan laku batin tidak lepas dari nilai spiritual ke-Ilahian, sehingga tidak bisa dipungkiri jika konsep-konsep dalam filosofi Jawa turut mewarnai.

Adapun bagian dari filosofi Jawa yang melekat pada bangunan adalah sangkan paraning dumadi. Dalam suatu kegiatan, sangkan-paran merupakan tujuan utama dilakukannya aktifitas. Maksudnya adalah apa yang mendorong suatu perbuatan, untuk apa dan siapa perbuatan tersebut dilakukan. Maksud ini berelasi dengan asal dan tujuan hidup manusia, dari tidak ada menjadi ada, berproses lalu kembali tiada. Sangkan-paran dumadi juga dapat dimaknai sebagai asal muasal manusia dan akhir keberadaan manusia.

Dalam terminologi Jawa ada 3 tahapan sangkan-paran, pertama; sangkaning dumadi, kedua; tataraning dumadi, dan ketiga; paraning dumadi. Sangkaning dumadi mencakup asal keberadaan manusia yakni dari Tuhan. Paraning dumadi adalah akhir keberadaan manusia yang disebut dengan istilah mulih mulanira. Tataraning dumadi adalah tingkat-tingkat pertumbuhan dan perkembangan manusia sejak diciptakan oleh Tuhan sampai kembali ke Tuhan. Dari sisi rohaniah, keberadaan manusia dapat dihayati melalui kawruh kasampurnan di tiga dimensi, (1) alam rahim yang meliputi keberadaan manusia sejak dalam rahim hingga dilahirkan oleh ibunya, (2) alam hayati meliputi keberadaan manusia sesudah lahir sampai mati, (3) alam kubur mencakup keberadaan manusia sejak mati sampai kembali dibangkitkan untuk dihisab.

Pembahasan mengenai dimensi estetika bangunan Keraton Kasunanan Surakarta dalam artikel ini akan dimulai dari sisi paling utara, yaitu Tugu Pamandengan. Tugu Pamandengan adalah titik akses utama dari arah utara 
menuju Keraton Kasunanan Surakarta. Tugu ini terletak di depan Balaikota Surakarta. Tugu Pamandengan adalah titik fokus pandangan mata batin Sri Susuhunan Pakubuwono ketika duduk di singgasana, Pagelaran Sumewa. Pamandengan berarti 'lihat', melihat bermakna tuntutan agar manusia memiliki ketajaman untuk melihat sesuatu yang ada di depan mata. Pamandengan juga bermakna waspada disertai ketajaman pikiran. Tugu ini juga merupakan simbol ketauhidan dalam Islam. Artinya, Sri Sunan beserta rakyatnya beriman dengan sepenuh hati pada ke-Esa-an Allah Swt. Tugu yang menjulang tinggi adalah tanda bahwa di atas kekuasaan Sri Sunan di keraton Surakarta masih terdapat kekuasaan yang lebih tinggi, yaitu kekuasaan Allah Swt. Demikian juga bagi rakyat, penghormatan dan rasa takut kepada pemimpin atau Sri Sunan tidak boleh mengalahkan rasa takut kepada Allah Swt sebagai Dzat yang Maha Tinggi dan berkuasa.

Bagian selatan Tugu Pamandengan, disebut komplek Alun-alun Lor sebagaimana disebutkan oleh KGPH Poeger meliputi Gapura Gladag, Pamurakan, Alun-Alun Utara dan Masjid Agung. Gapura adalah celah akses tanpa daun pintu di antara dua pilar, atau lubang tanpa daun pintu di antara dua pilar dan penghubung atas yang terletak antara ruang Profan Kasunanan (Alun-alun) dengan luar kasunanan atau di batas terluar suatu lingkungan atau wilayah teritori (Marlina, 2003). Gapura Gladak pertama kali dibangun oleh Pakubuwono III pada tahun 1750. Gapura Gladak adalah pintu masuk dari arah utara Keraton Surakarta. Desain gapura ini melengkung dan ditata bersebelahan antara kanan dengan kiri. Gapura Gladak telah beberapa kali direnovasi. Awalnya, Gapura Gladag merupakan pintu kayu yang beroda yang berbentuk melengkung dan dibuat dari besi yang dihias dengan beberapa gambar binatang buruan. Kondisi sekitarnya adalah tanah luas tempat kandang binatang hasil buruan. Sejarah Gladak dahulu adalah kandang binatang yang di dalamnya terdapat hewan-hewan hasil buruan, antara lain; rusa, dan kijang. Bila diperlukan maka hewan-hewan tersebut akan disembelih dengan cara dihela dengan tali atau istilahnya adalah anggladdag, sedangkan hanggladhak sendiri yang berarti menarik menuju tempat penyembelihan. Hubungan relasional antara fungsi tempat yang saat itu digunakan sebagai penarik hewan buruan dengan penamaannya sebagai Gladak adalah pasemon bahwa manusia dalam hidup manusia harus bisa mengendalikan keinginan yang kurang baik (Projosujitno, 1956: 2). Gapura Gladag menyimpan nilai pengingat bagi manusia agar dapat menguasai hawa nafsu yang cenderung pada naluri hewan, misalnya; bodoh dan saling berebut 
serta suka bertengkar dengan sesamanya. Pohon beringin kembar di Gladag adalah cermin bahwa segala sesuatu yang berbeda dapat berjalan sejajar dan beriringan serta saling melindungi. Alun-alun adalah peringatan kepada manusia agar menjadikan pengalaman sebagai guru serta berhati-hati dalam menjalani kehidupan. Alun-alun sendiri di sisi lain adalah lambang keadaan dunia dengan segala keadaannya, seperti; terang-gelap, suka-duka, kayamiskin, menang-kalah, sehat-sakit, tinggi-rendah dan sebagainya. Kondisi yang merupakan keniscayaan itulah yang perlu disadari oleh manusia agar mereka tidak mudah dipermainkan oleh keadaan sehingga dapat hidup dengan tentram.

Perombakan total gapura kemudian dilakukan oleh Paku Buwono X pada tahun 1913. Pada perombakan tersebut bentuk lama gapura diganti dalam bentuk bangunan baru yang dikenal dengan istilah 'Pagrogolan'. Saat ini Gapura Gladak memiliki bentuk menyerupai candi bentar dengan ornamen hias sejumlah 48 dan jeruji tembok juga sejumlah 48. Ada dua arca besar disamping kanan dan kiri gapura. Arca raksasa yang dibuat tahun 1930 di Pandansimping Klaten tersebut dikenal dengan sebutan Reca Pandita Yaksa. Keberadaan dua arca tersebut bermakna pengingat bagi manusia untuk menjadi makhluk pemberani yang tidak takut dengan cobaan hidup. Angka 48 sendiri sebenarnya merupakan angka peringatan ulang tahun Paku Buwono X yang pada saat pembangunan gapura berusia 48 tahun. Beberapa orang memaknai gapura menggunakan pendekatan Islam. Gapura atau yang dalam bahasa Jawa dikenal dengan 'gapuro' adalah terminology yang diadopsi dari bahasa Arab 'ghofuro' yang maknanya adalah memaafkan. Lanskap filosofis dari gapura sendiri bermakna proses kehidupan manusia yang terus berjalan. Manusia lahir, tumbuh dewasa, menua dan akan mati. Oleh sebab itu manusia harus memiliki sifat saling memaafkan. Makna yang tercermin dalam bentuk simbolis Gapura Gladak adalah langkah pertama seseorang dalam mencapai arah dan tujuan kehidupan. Alun dalam bahasa Jawa bermakna 'ombak', sedangkan dalam bahasa Arab berasal dari kata aluna. Ombak hanya ada di laut. Pemilihan kata alun yang berarti ombak dan hanya berhubungan dengan laut adalah karena kehidupan diibaratkan sebuah perjalanan mengarungi laut yang kadang berombak. Agar kehidupan manusia bisa selamat maka manusia membutuhkan perahu untuk mengarungi laut dan selamat dari ombak. Perahu yang dimaksud di sini adalah agama yang di dalamnya mengatur dimensi ketauhidan dan kepada siapa manusia harus beriman atau percaya. Sebagai muslim, manusia harus beriman hanya kepada Allah Swt 
sebagaimana diikrarkan dalam dua kalimat syahadat yang telah mereka ucapkan. Persaksian tersebut adalah bukti verbal bahwa mereka akan mempercayai bahwa tiada Tuhan selain Allah dan bahwa Muhammad adalah Rasulullah.

Persaksian dalam ikrar dua kalimat syahadat berkaitan dengan keberadaan dua pohon beringin di alun-alun. Pohon beringin yang dikurung di Alun-alun Lor dikenal dengan nama Waringin Dewadaru dan Waringin Jayadaru. Waringin Dewadaru adalah simbol keluhuran dan kesempurnaan, sedangkan waringin jayadaru adalah simbol kejayaan atau kemenangan. Di sisi utara Alun-alun ditanam juga dua pohon beringin yang dikenal dengan nama Waringin Jenggot dan Waringin Wok. Waringin Jenggot adalah representasi laki-laki sedangkan Waringin Wok adalah representasi perempuan. Makna dari penamaan pohon beringin yang diakhiri dengan 'daru'. Daru adalah merujuk pada makna daru sebagai cahaya atau 'nur' yang berarti petunjuk Allah kepada manusia. Apabila manusia mau menjalani hidup dengan memegang petunjuk Allah maka dalam mengarungi kehidupan yang diibaratkan ombak mereka tidak akan jatuh dan tenggelam.

Masjid Agung Keraton Kasunanan Surakarta adalah masjid yang termasuk dalam kategori masjid jami'. Selain digunakan untuk shalat lima waktu masjid juga dipakai untuk menunaikan shalat jumat dan kegiatankegiatan keagamaan lain oleh penghuni Keraton dan masyarakat umum. Masjid ini terletak di sebelah barat Alun-alun Lor. Bangunannya berdiri megah dengan arsitektur kuno yang memadukan unsur Jawa, Eropa dan Timur Tengah. Keagungan dan keanggunan masjid ini dapat dilihat dari Pasar Klewer, tempat perbelanjaan yang terkenal. Posisi Masjid Agung dengan Pasar Klewer mengingatkan pada hadist Nabi Muhammad tentang hubungan masjid dan pasar. Nasihat Nabi ini berkenaan dengan idiologi yang dianut oleh sebuah bangsa, agar tetap waspada antara aspek kontemplatif dengan aspek kompetitif. Unsur arsitektur pada Masjid Agung Keraton Surakarta ini memiliki ciri visual yang menyerupai rumah tradisional Jawa yang berpadu dengan konsep agama Hindu, yaitu bhurloka, bhurwaloka, dan swarloka (Yunianti, 2015). Bhurloka adalah simbolisasi dunia bawah yang dihuni oleh manusia, sedangkan bhuwarloka adalah simbol dunia antara (alam kematian), dan swarloka adalah symbol dunia atas yang merupakan alam para dewa. Relasi tersebut tampaknya bersinggungan ketika dihubungkan dengan fungsi masjid yang selain digunakan untuk beribadah, dipakai juga untuk kegiatan berkumpulnya manusia dengan tujuan tertentu. Selain digunakan untuk 
beribadah, masjid juga dipakai untuk menyelenggarakan berbagai upacara keagamaan keraton atau yang kita kenal dengan peringatan hari besar Islam. Masjid Agung dengan luas 19.180meter persegi ini terdiri dari Serambi masjid, Gedhong (ruang utama masjid), dan Pawastren (ruang shalat perempuan). Di dalam Gedhong dibuat maksura sebagai tempat shalat khusus Sri Sunan.

Secara garis besar, warna yang dominan dalam bangunan Masjid adalah warna biru muda dan coklat. Warna coklat pintu merupakan tandatanda atau denotasi yang mempunyai makna konotasi tingkat sakral yang lebih tinggi. Warna biru muda merupakan tanda-tanda atau denotasi yang dikonotasikan warna khas keraton. Lantai merupakan bagian dasar dari sebuah bangunan. Lantai di Masjid Agung Surakarta memiliki ketinggian yang berbeda-beda. Tingkatan tersebut dimaknai dari rendah ke atas, dari profan ke sakral. Semakin tinggi tempat, semakin tinggi tingkat kesakralan. Desain unsur-unsur bangunan berupa pintu, jendela, tangga lantai dengan jumlah 11, 5, 3, dilihat sebagai penandaan ikon dari situasi keagamaan pada waktu pendirian masjid. Konsep tersebut merupakan tanda-tanda atau denotasi yang dikonotasikan jumlah ganjil, dikonotasikan bilangan yang disukai oleh Allah SWT sehingga jumlah tersebut esensinya menuju ke Tuhan YME. Jumlah tiga dikonotasikan tentang Islam, Iman dan Ihsan. Jumlah lima dikonotasikan Rukun Islam yang berjumlah lima yaitu syahadat, sholat, puasa, zakat, dan naik haji. Di sinilah masjid tampil sebagai rumah peribadatan, perjumpaan khusus sementara antara manusia dengan Tuhan. Dalam terminology umum, masyarakat Indonesia mengenal istilah masjid sebagai rumah Allah. Keseriusan dalam penggarapan masjid tercermin dalam bentuknya khas. Nilai estetika dapat dilihat dari penataan ruang, bentuk-bentuk unsur bangunan dan pemilihan warna yang gunakan di setiap ruang dan unsur yang membentuk bangunan Masjid Agung Keraton Surakarta.

Sesuai dengan konsep nilai yang diungkapkan oleh Setiadi dalam (Koentjaraningrat, 2010: 145), unsur arsitektur bangunan Masjid Agung Surakarta memiliki nilai yang dapat diambil dari maknanya, terutama nilai religius. Religi mengandung segala keyakinan bayangan manusia tentang sifat-sifat tuhan, tentang alam ghaib, tentang segala nilai, norma dan ajaran religi yang bersangkutan. Sedangkan tata cara ritual dan upacara merupakan usaha manusia untuk menjalin hubungan dengan sang pencipta, dewa-dewa, makhluk-mahkluk halus yang mendiami alam gaib (Koentjaraningrat, 2010: 145). Masyarakat percaya bahwa agama telah menjadi kekuatan pembentukan sikap yang baik. Hal ini yang membuktikan bahwa masjid sarat akan nilai 
pendidikan. Di dalam masjid diyakini terkandung nilai yang bermanfaat bagi kehidupan masyarakat. Di dalamnya mengandung nilai yang cocok dimanfaatkan dalam banyak hal, salah satunya sebagai pengayaan materi seni tentang unsur arsitektur bangunan Masjid Agung Surakarta dan pembentukan sikap yang baik khususnya keTuhanan.

Sebelah selatan Alun-alun Lor (utara) adalah Sasana Sumewa adalah bangunan utama yang terletak paling depan dari Keraton Kasunanan Surakarta. Penyematan nama pada Sasana Sumewa adalah adopsi dari Bahasa Jawa anggelar, Arab amar makruf nahi munkar. Pada awalnya, Sasana Sumewa digunakan untuk tempat pertemuan para punggawa pada acara resmi keraton. Para punggawa tersebut selanjutnya menerima perintah dan nasehat dari raja, selain menyampaikan pertanggung jawaban mereka atas kinerja yang telah dilakukan. Pada awalnya, Sasana Sumewa dibangun menggunakan bambu dengan jumlah tiang kurang lebih 200 buah (KGPH Poeger, 2019). Banyaknya tiang tersebut secara tidak langsung memberikan gambaran kepada kita tentang luas ruangan yang tentunya tidak seperti ruangan-ruangan pada bangunan biasa. Bentuk ruang Sasana Sumewa yang luas mencerminkan suatu kelapangan dan dapat diasosiasikan dengan anjuran untuk memiliki hati yang lapang. Filosofi dari sasana sumewa sendiri nampaknya tidak jauh dari penamaan Sumewa yang juga berarti pagelaran. Pagelaran diambil dari bahasa Jawa 'gelar' yang identik dengan tempat yang luas.

Sasana Sumewa direnovasi pada masa kekuasaan Pakubuwono X. Tiang bangunan yang pada awalnya sebanyak kurang lebih 200 dipangkas dan diperbarui menjadi sebanyak 48. Jumlah 48 disesuaikan dengan usia Pakubuwono yang saat itu adalah 48 tahun. Saat ini sasana sumewa difungsikan sebagai tempat berbagai acara publik, misalnya, pertunjukan kesenian, dan pameran-pameran. Sasana Sumewa terdiri dari bangunan utama dan bangunan-bangunan kecil di dalamnya. Bangunan-bangunan kecil tersebut adalah bangsal pangrawit, bangsal pacekotan, dan bangsal pacikeran. Bangsal Pangrawit berasal dari rumah kecil bekas kapal Jenggala yang dibawa dari Kartasura. Dahulu, bangsal ini berfungsi sebagai singgasana raja pada saat menyampaikan perintah kepada para bawahannya. Selain itu, bangsal ini juga digunakan untuk melantik pera pejabat keraton. Adapun bangsal pacekotan digunakan untuk tempat penyelenggaraan momen pemberian anugerah raja kepada bawahannya. Selain itu bangsal ini juga biasa dipakai sebagai tempat berdiskusi para abdi dalem ketika terdapat permasalahan. Sedangkan Bangsal Pacikeran adalah bangsal yang disetting terbuka yang 
berfungsi sebagai ruang tunggu bagi orang yang akan mendapatkan hukuman dari pengadilan keraton atau raja. Pacikeran juga bisa bermakna tempat untuk orang-orang yang melakukan kesalahan. Posisi bangsal ini di bagian depan sisi barat pagelaran. Pada dasarnya fungsi dari bangunan ini tidak jauh dari penamaannya, Pacikeran. Pacikeran berasal dari kata 'ciker' atau jika dirunut kedalaman maknanya maka akan sampai pada makna 'tangan yang diputar/ puter tangane'(Nilasari, 2013: 28).

Sitihinggil pada awalnya dikenal dengan sebutan Siti Bentar yang dibangun oleh Paku Buwono III pada tahun 1771 dengan nama lengkap Siti Inggil Binata warata atau Siti Inggil Palenggahaning Ratu. Sitihinggil merupakan suatu kompleks yang dibangun di atas tanah yang lebih tinggi dari sekitarnya. Filosofi dari pembangunan Sitihinggil utara adalah gambaran dari perjalanan hidup manusia menuju tingkatan (maqam) yang lebih tinggi atau proses menuju insan kamil (manusia sempurna). Kompleks ini memiliki beberapa bangunan diantaranya Bangsal Sewayana, Bangsal Manguntur Tangkil, Bangsal Witana, Bangsal Manguneng, Bangsal Gandhek Tengen, Bangsal Angun-Angun, Bangsal Balebang, Bangsal Gandhek Kiwa, Kori Wijil, Aling-Aling, Dan Kori Renteng. Kompleks Sitihinggil digunakan untuk penobatan raja (Rully, 2013).

Sitihinggil Utara dibangun pada masa kekuasaan Paku Buwono III bersamaan dengan pembangunan Sitihinggil Selatan pada tahun 1701 Jawa, atau 1774 masehi atau tahun Alip 1691. Adapun perbedaan antara Sitihinggil Utara dengan Selatan hanya pada pagelaran. Pada Sitihinggil Selatan tidak terdapat bangunan pagelaran. Ada sebanyak 8 buah anak tangga dan 2 pintu yang menghubungkan antara Sitihinggil Utara dengan Pagelaran. Pintu-pintu tersebut biasa disebut dengan nama Kori, yaitu Kori Wijil I dan Kori Wijil II. Kori adalah penghubung antara ruang publik dengan ruang individu yang memiliki bermacam-macam wujud, bisa lubang tanpa atap, lubang yang beratap, ruangan beratap, bahkan dinding berlubang yang membagi suatu ruangan ( Marlina, 2003). Intinya, wujud kori atau lawang (bahasa Jawa) tidak merubah fungsi awalnya sebagai alat pengelola interaksi. Sedangkan wijil artinya sesuatu yang keluarnya dari lisan dan hati. Bangsal Sewayana dalam Kompleks Sitihinggil Utara berfungsi sebagai tempat transit para tamu undangan, bangsawan dan kerabat abdi dalem yang akan mengahadap raja. Makna simbolis yang dituturkan dari bangsal sewayana adalah tempat persinggahan. Kehidupan hanyalah persinggahan sejenak untuk sekedar makan atau minum. Filosofi dari bangsal sumewa adalah agar manusia selalu 
ingat bahwa hidup adalah perjalanan yang harus segera dilanjutkan sehingga kesempurnaannya berorientasi kepada Tuhan dapat direalisasikan.

Konsep kosmologi terwujud pada tata letak keseluruhan bangunan di Sitihinggil Utara, di mana Bangsal Manguntur Tangkil merupakan pancer/pusatnya, yang merupakan pusat daya pancer/pusatnya prabawa sehingga dianggap pula sebagai pusat segala kekuatan supranatural (daya gaib) di Sitihinggil Utara. Konsep dualisme, tata letak bangunan di Sitihinggil Utara terwujud pada Bangsal Sewayana merupakan dualisme dari Bangsal Manguntur Tangkil. Bangsal Witono merupakan dualisme dari Bangsal Manguneng. Bangsal Agun-angun merupakan dualisme dari Bangsal Balebang. Bangsal Gandhek Kiwa merupakan dualisme Bangsal Gandhek Tengen. Hirarki tampak dari posisinya di kontur tanah lebih tinggi dibandingkan bangunan yang memiliki nilai hirarki yang lebih rendah, pada Sitihinggil Utara bangunan yang mempunyai nilai hirarki tinggi adalah Bangsal Manguntur Tangkil karena terkait dengan fungsinya sebagai tempat duduk raja.

Untuk masuk pada komplek Sri Manganti Lor kita harus melewati pintu gerbang yang dikenal dengan sebutan Kori Kamandungan. Kompleks Kamandungan merupakan pintu masuk kedalam kedhaton setelah melewati Kori Brajanala (brajanala) atau Kori Gapit merupakan pintu gerbang masuk utama dari arah utara ke dalam halaman Kemandungan utara. Gerbang ini sekaligus menjadi Gerbang Cepuri (kompleks dalam istana yang dibatasi oleh tembok besar). Gerbang ini dibangun oleh Susuhunan Paku Buwono III dengan gaya Semar Tinandu. Pada Kori Kamandungan diletakkan lukisan besar lambang kerajaan Jawa Islam 'Sri Makutaraja'. Istilah kamandungan diambil dari kata mandung yang berarti berhenti. Filosofi dari penamaan Kori Kamandungan ini adalah bahwa manusia akan mengalami kewajiban memenuhi panggilan kembali ke asalnya (marlina, 2003). Secara leksikal, istilah kamandungan menurut folklore memiliki asal kata mandu yang berarti magang atau calon yang berarti calon mati. Oleh sebab itu makna kamandungan dekat dengan interpretasi peringatan kepada manusia bahwa sautu saat mereka akan mati (Nilasari, 2013: 17).

Kori Kamandungan (mandung; berhenti) menyimpan nilai bahwa manusia harus berhenti untuk mengingat kembali atau mengoreksi perbuatan yang telah dilakukan pada masa lalu. Apabila dalam proses introspeksi tersebut ditemukan bahwa ada kesalahan masa lalu yang telah dilakukan maka dia harus segera meminta ampunan (Jawa; mertobat) dan mengucap 
syukur atau berterima kasih apabila mendapatkan banyak rahmat dari Allah Swt.(avi marlina, 2003) Selain lukisan Sri Makutaraja, di Kori Kamandungan dipasang cermin toilet besar yang dikenal dengan istilah kaca wirangi. Cermin ini bermakna mawas diri, meneliti diri sendiri baik lahir maupun batin. Secera lahiriah, seseorang dianjurkan untuk meneliti sejauh mana kerapian berpakaian mereka sesuai dengan kepangkatannya sebelum menghadap ke Keraton. Secara batiniah manusia dianjurkan untuk meneliti diri sendiri secara batin dalam rangka pembersihan diri dari pikiran buruk dan batin yang kurang prayogo, hati-hati dalam bertindak dan tidak boleh semaunya sendiri. Tujuan dari pembersihan lahir dan batin manusia adalah untuk melancarkan perjalanan menuju alam kelanggengan. Selain lukisan dan cermin besar di kanan kiri Kori sebelah dalam juga terdapat gambar firasat pria dan wanita yang dikenal dengan istilah budaya sebagai lingga dan yoni. Kedua gambar firasat tersebut mengandung arti bahwa hidup tidak mungkin terjadi tanpa perantara ayah dan ibu dengan ridho Ilahi. Lingga dan Yoni juga merupakan godaan terbesar manusia, godaan terbesar pria adalah wanita dan godaan terbesar wanita adalah pria. Godaan tersebut harus dicegah agar manusia mendapatkan kelancaran sampai ke Alam Kejaten.

Bangsal Sri Manganti lor biasanya digunakan sebagai tempat penjagaan sekaligus ruang tunggu tamu agung yang akan menghadap raja. Ada bangunan utama di sana, yaitu Bangsal Samarakatha yang berada di sebelah barat dan Bangsal Marcukundhha di sebelah timur. Selain sebagai tempat yang difungsikan sebagai ruang tunggu, bangunan Sri Manganti juga dimaknai sebagai tempat perenungan bagi manusia dalam menaklukkan hawa nafsu. Kompleks Kedathon ini juga biasa disebut dengan istilah Sasana Sewaka. Kompleks Sasana Sewaka adalah inti Keraton yang berfungsi sebagai tempat untuk menerima tamu agung dan para kerabat abdi dalem yang akan menghadap raja untuk menghadiri acara ulang tahun, kenaikan tahta, dan lain-lain (Haryono, 2010). Se ana Sewaka terdiri dari bangsal Maligi, Paningrat, Pendapa Ageng Sasana Sewaka, paningrat Bedayan dan Sasaka Prasedya (Sari, 2010). Bangsal-bangsal tersebut berorientasi menghadap kearah timur menghadap matahari terbit karena dalam kepercayaan Jawa Tuhan direpresentasikan oleh terbitnya matahari sehingga apabila seseorang bersemedi maka sebagian besar mereka menghadap ke arah timur. Bangsal Maligi adalah bagian yang terletak paling dalam. Ruangan tersebut diinterpretasikan sebagai wujud dari pengalaman batin manusia saat bertemu dengan Tuhan setelah sebelumnya menyucikan diri di bangsal-bangsal 
sebelumnya. Di sebelah selatan Sasana Sewaka terdapat Sasana Handrawina yang biasa digunakan oleh raja untuk menjamu tamu-tamu asing.

Kompleks magangan ini adalah tempat pusat administrasi Keraton Surakarta dilakukan. Magang dalam bahasa Jawa adalah belajar bekerja. Magangan merupakan tampilan simbolik dari perintah atau anjuran agar manusia belajar bekerja. Proses administrasi yang berpusat di Magangan adalah penanda bahwa manusia harus bisa memanfaatkan waktu mudanya untuk belajar, dan bekerja (KGPH Poeger, 2019). Dimensi estetika dalam bangunan Sri Manganti Kidul (Selatan) dan juga Sri Manganti Lor (Utara) adalah simbolisasi perpindahan kehidupan manusia dari dunia ke akhirat. Relasi antara Sri Manganti dengan Kamandungan terletak pada proses yang harus dijalani manusia selama kehidupannya. Setelah manusia menyucikan diri dengan selalu mawas diri maka hubungan antara manusia dengan sesama manusia, dan manusia dengan Tuhan akan terjalin secara harmonis. Artinya, manusia menjadi bersih dari kesalahan serta mendapatkan ampunan dari Tuhan dan berakhir pada surga di kehidupan kekal nanti. Oleh karena itu Kori Kamandungan Lor (Utara) sampai dengan Sri Manganti Kidul (Selatan) sebenarnya adalah simbolisasi perjalanan hidup manusia.

\section{Identitas Budaya dalam Bangunan Keraton Kasunanan Surakarta}

Unsur-unsur dalam bangunan Keraton Kasunanan Surakarta merupakan hasil akulturasi dari beberapa kebudayaan. Hal itu bisa kita lihat dari bentuk arsitektur bangunan, berbagai ornament hiasan yang memperindah bangunan, serta pilihan warna di tiap bangunan. Arsitektur bangunan keraton tampak menampilkan bentuk khas model rumah masyarakat Jawa, yaitu bentuk Joglo maupun Limasan dengan tambahan unsur kayu sebagai pintu, jendela dan atap. Ornament ruangan dan hiasanhiasan di setiap unsurnya mengisayaratkan nuansa modern Barat. Lampu gantung di beberapa sasana misalnya. Lampu-lampu gantung yang terbuat dari kristal adalah simbolisasi dari bentuk kemewahan dan gaya interior modern-klasik-Eropa. Adapun identitas Islam sebenarnya tidak tampak jelas karena tidak ada satupun bangunan selain masjid dan bentuk gapura masjid yang secara khusus melambangkan sebagian unsur Islam. Identitas Islam baru akan dapat dilihat secara umum setelah dilakukan pemetaan dan penyisiran seluruh unsur pada komplek bangunan Keraton. Hal itu disebabkan oleh adanya dimensi internal-metafisik yang melandasi ide dari pembangunan unsur-unsur keraton. Dengan demikian paling tidak, terdapat 
tiga representasi identitas di hampir setiap detail bangunan pada Keraton Kasunanan Surakarta, yaitu identitas Jawa, Eropa dan Islam.

Mengacu pada konsep simbol Geertz tentang adanya unsur semiotic dalam kebudayaan, terlihat bahwa sebenarnya identitas Islam sudah bisa dilihat pada bentuk penamaan beberapa unsur bangunan, mulai dari Tugu Pamandengan sebagai titik pusat meditasi Sri Sunan ketika lenggah. Tugu Pamandengan adalah titik fokus Sunan untuk meminta hidayah dan petunjuk kepada Yang Maha Tinggi, Sang Khaliq, Allah Swt. Tugu Pamandengan memiliki struktur bangunan yang bagian atasnya lebih kecil daripada bagian bawah (kaki tugu). Pamandengan, yang memiliki akar kata pandeng (dalam bahasa Jawa berarti melihat dengan tajam penuh konsentrasi) berasosiasi dengan anjuran dalam Islam bahwa pada saat berdoa manusia diharapkan fokus dan pasrah kepada Allah Swt. Anjuran ini sejalan konsep teleologis, yaitu melayani tujuan penciptaan Allah Swt. Salah satu tujuan penciptaan manusia adalah sebagai pemimpin (khalifah) di muka bumi. Pemfungsian Tugu Pamandengan sendiri sebagai titik fokus Sri Sunan adalah simbolisasi dari fungsi khalifah yang juga sebagai pelindung kebudayaan (Natsir, 1988).

Sedikit bergeser ke selatan, yaitu Gladag. Memang tidak didapatkan sumber yang menyatakan tentang darimana dan siapa yang memberi nama Gapura Gladag, namun dari penelusuran filosofi penamaannya, Gladag memiliki makna yang melampaui penamaannya sebagai Gladag. Gladag yang memiliki akar penamaan dengan tujuan spiritual pengelolaan terhadap hawa nafsu manusia, baik nafsu yang baik maupun nafsu yang buruk. Perintah dan tujuan pengelolaan hawa nafsu memang terdapat dalam seluruh agama, akan tetapi nafsu baik (mutmainnah) dan nafsu jelek (amarah) adalah adopsi dari jenis nafsu yang dikenal dalam Islam. Hal ini selanjutnya berbeda pada saat kita mengamati bentuk gapura. Gapura atau yang dalam bahasa Jawa dikenal dengan gapuro adalah peninggalan kebudayaan Hindu Budha. Ajaran Hindu Budha mewarnai kebudayaan masyarakat Jawa melalui masuknya orangorang India sebelum Arab, Cina, Portugis dan Belanda. Dalam kurun waktu lebih dari 1500 tahun masyarakat Jawa menyaksikan keluar masuknya orangorang asing tersebut dengan menyerap kebudayaan yang mereka bawa (Roberton, 1980: 206). Pemilihan Islam sebagai representasi utama selain agama-agama lain didasarkan pada berbagai filosofi bangunan dalam Keraton. Ada beberapa makna implisit yang mengandung maksud untuk menjaga hawa nafsu dan memegang prinsip hidup sederhana. 
Identitas Islam dan Jawa terepresentasi salah satunya dalam komposisi bangunan Keraton dari arah utara ke selatan. Formulasi bangunan bagian utara tampak lebih mewah dibandingkan dengan unsur-unsur dalam beberapa bangunan di arah selatan. Beberapa simbol kemewahan tampak pada bangunan Keraton, terlebih Sitihinggil Utara dengan Selatan. Ada perbedaan yang sangat mencolok antara kedua bangunan tersebut. Sitihinggil utara memiliki struktur bangunan yang lebih modern dengan sentuhan klasik Jawa, sedangkan Sitihinggil selatan tampil dalam bentuk sangat sederhana, bahkan nyaris tanpa ornament hiasan. Sitihinggil selatan lebih bisa diakses oleh masyarakat secara luas. Makna dari penataan unsur-unsur keraton tersebut adalah simbol perjalanan hidup manusia dengan segala rintangan dan usahanya menuju kesempurnaan hidup sebagai manusia yang sejati. Perjalanan tersebut telah melalui ujian dan cobaan sehingga manusia sampai pada titik klimaks mereka dalam posisinya sebagai manusia sehingga berserah diri pada Allah Swt. Melalui simbolis masjid. Masjid adalah tempat manusia berinteraksi dan komunikasi dengan Sang Maha Pencipta.

Ornament dan hiasan yang menurut saya adalah representasi dari modernitas bangsa Belanda-Eropa berasal dari historisitas lahirnya Keraton Kasunanan Surakarta yang melibatkan bangsa Belanda. Bangsa Belanda berperan penting dalam pembentukan keraton karena Pakubuwono II sebelumnya meminta bantuan kepada Belanda dengan imbalan tertentu. Penampakan simbolis Belanda pada unsur hiasan pada beberapa bagian keraton jika dilihat dari berdasarkan teori tindakan sebagai mana dipopulerkan oleh Weber, mengandung maksud dan tujuan. Di sisi lain Bangsa Belanda dalam konteks ini memiliki maksud dan tujuan yang mengarah pada eksistensi sosial sebagai bangsa penguasa yang memiliki wilayah-wilayah jajahan. Beberapa simbol yang mengarah pada gaya hidup modern Bangsa Belanda juga bisa kita bandingkan sejarah masyarakat Jawa yang saat itu masih dalam bentuk-bentuk masyarakat sederhana dengan pola hidup yang sederhana pula. Masyarakat Jawa belum mengenal lampu-lampu hias. Untuk tujuan menerangi aktifitas di malam hari, mereka masih biasa menggunakan obor atau lampu temple dengan bahan bakar minyak tanah. Sementara lampu-lampu kristal tentu tidak cukup hanya dengan minyak tanah serta perawatan yang cenderung sederhana serta mudah.

Mendiskusikan perihal identitas Jawa dalam unsur Keraton Kasunanan Surakarta tentu tidak bisa dilepaskan dari bentuk bangunan dengan atap dan material lainnya yang merepresentasikan ke-Jawa-annya. Dalam tradisi 
masyarakat Jawa dikenal adanya bentuk-bentuk rumah, misalnya; limasan, srotong, joglo, panggangepe, daragepak, macan njerum, klabang nyander dan rumah sinom. Bentuk-bentuk tersebut juga memiliki spesifikasi tersendiri atas penghuninya. Adapun bentuk Joglo sebagaimana ditemukan dalam banyak bangunan Keraton adalah prototype untuk kalangan bangsawan, meskipun saat ini banyak orang membuat rumah dengan gaya bangunan Joglo. Bahkan di kota-kota besar, gaya atap rumah yang berbentuk joglo banyak kita jumpai. Pilihan gaya bangunan tersebut juga sebenarnya adalah tanda dan simbolisasi dari strata sosial pemiliknya.

\section{Simpulan}

Nilai estetika dalam bangunan Keraton Kasunanan Surakarta dapat dilihat dari berbagai macam keindahan yang ditampilkan secara khusus pada penataan bangunan serta berbagai variasi yang melekat pada bangunan tersebut. Penataan bangunan Keraton Kasunanan Surakarta adalah simbolisasi atas perjalanan hidup manusia yang berpijak dari nilai-nilai religius yang mengarah pada nilai ke-Ilahian. Konsep filosofi Jawa yang menjadi simbolisasi bangunan Keraton Kasunanan yaitu filosofi Jawa Sangkan Paraning Dumadi. Dalam suatu kegiatan, sangkan-paran merupakan tujuan utama dilakukannya aktifitas. Maksudnya adalah apa yang mendorong suatu perbuatan, untuk apa dan siapa perbuatan tersebut dilakukan. Maksud ini berelasi dengan asal dan tujuan hidup manusia, dari tidak ada menjadi ada, berproses lalu kembali tiada. Sangkan-paran dumadi juga dapat dimaknai sebagai asal muasal manusia dan akhir keberadaan manusia. Dalam terminology Jawa ada 3 tahapan sangkan-paran, pertama; sangkaning dumadi, kedua; tataraning dumadi, dan ketiga; paraning dumadi.

Dalam konteks identitas, bangunan Keraton menyimpan makna akan adanya akulturasi dari tiga kebudayaan, yaitu kebudayaan Islam, kebudayaan Hindu-Jawa dan kebudayaan Eropa. Kebudayaan Islam tercermin dari adanya masjid secara materiil dan makna penataan bengunan-bangunan yang mengarah pada nilai-nilai tasawuf yang berbasis pada kesederhanaan dan konsep Zuhud. Kebudayaan Hindu-Jawa terlihat dari model atap bangunan dan pemilihan warna cokelat di beberapa bagian bangunan, serta pemilihan bunga yang ditanam di sekitar bangunan keraton. Warna cokelat adalah warna yang identik dengan kebudayaan Jawa, sedangkan bunga memiliki asosiasi makna yang dekat dengan kepercayaan Hindu-Jawa. Adapun kebudayaan 
Eropa terlihat dari kemewahan lampu-lampu hias yang digantung di beberapa bagian bangunan khusus.

\section{Referensi}

avi marlina. (2003). gapura dan kori karaton kasunanan surakarta dalam aspek simbolis.

Barker, C. (2009). Cultural Studies.

Cessirer, E. (1987). Manusia dan Kebudayaan Sebuah Esei Tentang Manusia ( alois a Nugroho, Ed.). Jakarta.

Dwi Ratna Nurhajarini, D. (1999). Sejarah Kerajaan Tradisional Surakarta. Jakarta: Departemen Pendidikan dan Kebudayaan RI.

Friedman, J. (1995). Cultural Identity and Global Process.

Haryono. (2010). Pendhapa Sasana Sewaka Keraton Kasunanan di Surakarta; Mitologi dan Makna Simbolis. Jurnal Seni Budaya, 8(2). Diambil dari https://jurnal.isiska.ac.id/index.php/gelar/article/view/1337/1319

Hobart, M. (2013). Theoretical Issues in the Study of Society and Culture.

Jenkins, R. (2004). Social Identity (second edi). Routledge.

KGPH Poeger. (2019). Unsur dalam Bangunan Keraton Kasunanan Surakarta.

Koentjaraningrat. (2010). Manusia dan Kebudayaan di Indonesia. Jakarta: Djambatan.

Manalu, S. R., Santosa, H. P., \& Luqman, Y. (2007). Teori Relational Dialectics Dalam Konteks Relasi Budaya Jawa. JIS: Jurnal Ilmu Sosial, 6(1).

Natsir, M. (1988). Kebudayaan Islam dalam Perspektif Sejarah. Bandung: Girimukti Pasaka.

Nilasari, R. (2013). Analisis Morfosemantis Nama-nama Bangunan di Kompleks Keraton Surakarta. UNY.

Projosujitno. (1956). Keraton Surakarta. Solo: Perpustakaan Keraton Surakarta.

Rapoport, A. (1982). The Meaning of The Built Environtment 'a Non Verbal Communication".' Beverly Hills.

Roberton, R. (1980). Agama dalam Analisa dan Interpretasi Sosiologis. Jakarta: Rajawali Press.

Roikan. (2013). Gapura Kampung dan Ketahanan Identitas. Ranah, 80-87.

Rompaey, C. van. (2017). The Concept of Beauty in Alexander BaumgartenÕs Aesthetica. Presented at the Australasian Society for Continental Philosophy Annual Conference. Hobart: University of Tasmania.

Rully. (2013). Perwujudan Simbolisme Lansekap Sitihinggil Utara Keraton Surakarta Hadiningrat. 
Sajid, R. . (1984). Babad Sala. Solo: Perpustakaan Istana Mangkunegaran.

Santosa, I. (2007). Kajian Estetika dan Unsur Pendukungnya pada Keraton Surakarta. 1(1), $108-127$.

Sari, G. P. (2010). Sasana Sewaka: Tinjauan Semantik Arsitektur Jawa Kraton Kasunanan Surakarta. Dimensi Interior, Vol. 8, No. 1, Juni 2010: 38-43, 8(1), 8-43.

Suseno, F. M. (1984). Etika Jawa. Jakarta: Gramedia.

Winarti. (2002). sekilas sejarah Karaton Surakarta. Sukoharjo:Cendrawasih.

Woodward, M. R. (1999). Islam Jawa (1 ed.; H. Salim, Ed.). Yogyakarta: LKiS.

Yunianti, E. (2015). Estetika Unsur-unsur Arsitektur Bangunan Masjid Agung Surakarta. Catharsis: Journal of Arts Education , 4(1). 
Halaman ini sengaja untuk dikosongkan 